necessary to apply to the magistrate for an order. Imported disease from unprotected places figures larmely in the returns, inasmuch as out of 612 prostitutes who were known to have arrived from places ontside the Acts, 404 (66 per cent.) were found on their first medical examination to be diseased, and a large proportion of them seriously. These imported cases form nearly a fourth of the total number of women (1849) admitted to the various Lock hospitals during the year, and they are especially fruitful in spreading venereal diseases, as there is no possibility of reaching them until they are discovered by the police and brought up for medical examination. With regard to the work of reclamation, the beneficent value of which can scarcely be estimated, we find 93 young girls under eighteen, 86 women under thirty, and 7 above that age have been rescued from bad company and immoral places. Of these 13 were under fifteen years of age. Besides these 174 had commenced an immoral life, but abaudoned it on being cautioned, and are therefore not registered. Of these 4 were under fifteen, and 45 under eighteen years of age. The difference between the amount of disease in those who were examined for the first time and those who were on the register from the previous year is very startling, and deserves great attention from the advocates of repeal, for in the former case 40.95 per cent. were found to be diseased, whilst in the latter it amounted to only about 8 . The number of the women in both classes was so nearly equal as to prevent the statistics being vitiated by any error of average numbers.

In conclusion, we may refer to a few points which have attracted our notice in making this analysis. In Portsmouth there are 30 prostitutes under eighteen years of age, including 2 under fifteen, 4 under sixteen, and 9 under seventeen. In no other district is there one under sixteen. In Chatham there are 2 under seventeen, and in Aldershot and Colchester 1, whilst in other districts they all exceed this age. These facts should surely command the attention of the various reformatory agencies in those towns. Again, in Devonport, out of 287 newly registered women, 133, or nearly one-half, were found to be diseased on being medically examined; and Dover (50 per cent.), Colchester (52), Aldershot (62), and Maidstone $(63)$ even exceeded this proportion. In the case of previously registered women the greatest proportion of venereal cases existed at Deal (30 per cent), Winchester (22), and Aldershot (13); whilst Sheerness, Windsor, and Gravesend were, as far as such women were concerned, entirely free from venereal diseases at the time of the first medical examination.

\section{THE ROYAL COMMISSION ON THE MEDICAL} ACTS.

(From The London Gazette, May 3rd, 1881.) WHITEHALL, MAY 2ND, 1881.

THE Queen has been pleased to issue a Commission under Her Royal Sign Manual in words and to the effect following:VICTORIA, R.

VICTORIA, by the Grace of God of the United Kingdom of Great Britain and Ireland Queen, Defender of the Faith, to our right trusty and right well-beloved cousin Robert Adam Philips Haldane, Earl of Camperdown; the Right Reverend Father in God William Connor, Bishop of Peterborough; our right trusty and well-beloved Councillor William Henry Ford Cogan ; our right trusty and well-beloved Councillor Sir George Jessel, Knight, Master or Keeper of the Rolls and Records in Chancery; our right trusty and well-beloved Councillor George Sclater-Booth; our trusty and wellbeloved Sir William Jenner, Baronet, Knight Commander of our Most Honourable Order of the Bath; our trusty and well-beloved John Simon, Esquire, Companion of our Most Honourable Order of the Bath; our trusty and wellbeloved Thomas Henry Huxley, Esquire, Doctor of Laws; our trusty and well-beloved Robert McDonnell, Esquire, Doctor of Medicine; our trusty and well-beloved William Turner, Esquire, Bachelor of Medicine; and our trusty and well-beloved James Bryce, Esquire, greeting!

Whereas it is of importance to all classes of our subjects that the conditions under which persons are permitted to represent themselves as qualified medical practitioners should be such as to afford the best attainable security for their skill and knowledge in medicine and surgery.

And whereas powers in relation to the education and examination for a grant of medical degrees, diplomas, or licences, to medical practitioners are by various statutes and charters vested in certain universities, medical colleges, and other bodies in the United Kingdom.

And whereas under "The Medical Act, 1858," and the Acts amending the same, the General Conncil of Medical Education and Registration was constituted, and vested with a superintendence over the exercise of the said powers, and also with entering in a register of medical practitioners, and removing therefrom the holders of certain medical quali. fications obtained in the United Kingdom, exclusive of those obtained in our colonies or in foreign States.

And whereas by the last-mentioned Acts certain exclusive privileges were conferred on the persons so registered, and persons not so registered were placed under certain restric. tions, disabilities, and penalties.

And whereas divers representations have been made in Parliament, and otherwise, and both from our subjects in the United Kingdom, and from the Governments of our possessions out of the United Kingdom, in relation to the unsatisfactory position of the above matters.

And whereas we have thought it expedient that, with a view to legislation, further inquiries should be made into the above matters, and that a commission should forthwith issue to inquire into the grant of medical degrees, memberships, fellowships, licences, and other diplomas by uni versities, colleges, and bodies in the United Kingdom, and the courses of education and examination, payments, and other conditions required as a preliminary to such grant, and into the skill and knowledge which such degrees, memberships, fellowships, licences, or diplomas represent; and further to inquire into the conditions and manner under or in which medical practitioners are entered in and are struck off the register of medical practitioners, and the privileges of registered and the disabilities of unregistered practitioners and the position of medical practitioners so registered in our possessions out of the United Kingdom, and the position in the United Kingdom of medical practitioners educated in our possessions out of the United Kingdom, or in a foreign State

And further to inquire into the constitution, functions, powers, and procedure of the General Council of Medical Education and Registration, and their relation to the above mentioned universities, colleges, and bodies, and to the medical profession.

And further to inquire into the result of "The Medical Act, 1858," and the Acts amending the same, and into all matters dealt with by those Acts.

Now know ye, that we, reposing great trust and confidence in your knowledge, discretion, and ability, have authorised and appointed, and do by these presents authorise and appoint you, the said Robert Adam Philips Haldane, Earl of Camperdown, William Connor, Bishop of Peterborough, William Henry Ford Cogan, Sir George Jessel, George SclaterBooth, Sir William Jenner, John Simon, Thomas Henry Huxley, Robert McDonnell, William Turner, and James Bryce, to be our commissioners for the purposes aforesaid.

And for the better effecting the purposes of this our com. mission, we do give and grant unto you, or any three or more of you, full power and authority to call before you, or any three or more of you, such persons as you shall judge necessary by whom you may be the better informed of the truth on the subjects herein submitted for your consideration, and every matter connected therewith; and also to call for, have access to, and examine all such books, documents, papers, and records as may afford the fullest information on the subjects of this inquiry; and to inquire of and concerning the premises by all other lawful ways and means whatsoever.

And our further will and pleasure is that you, or any three or more of you, do report to us, with all convenient speed, under your hands and seals, the result of your inquiries into the above matters, and what amendments are required in the above-mentioned Acts, and what provisions it is expedient to make in the matters above-mentioned, or any of them.

And we further will and command, and by these presents ordain, that this our commission shall continue in full force and virtue, and that you, our said commissioners, or any three or more of you, may from time to time proceed in the execution thereof, although the same be not continued from time to time by adjournment.

And for the purpose of aiding you in such matters, we hereby appoint our trusty and well-beloved John White, Esquire,

Barrister-at-Law, to be Secretary to this our commission.

Given at our Court at Saint James, the thirtieth day of A pril, one thousand eight hundred and eighty-one, in the forty. fourth year of our reign. - By Her Majesty's Command, 


\section{THE LANCET.}

\section{LONDON : SATURDAY, MAY \%, 1881.}

A Royal Commission has been appointed to investigate the working of the Medical Acts, and, at length, consider the necessity for amendments of them. The following is the list of names as they appeared in The Gazette of Tuesday last:--The Earl of CAMPERdown, the Bishop of PETERBoRocgh, iRight Hon. W. H. F. CogaN, the Master of the Rolls (Sir GEORGE JESSEL), Right Hon. G. Schater-BOoth, M.P., Sir Wildiam Jenner, Bart., M.D., J. Srmon, Esq., C.B., Professor Huxley, Dr. Robert McDonnell (Dublin), Professor Turner (Edinburgh), J. Bryce, Esq., M.P., with JOHN WHITE, Esq., Barrister-at-law, as secretary. Our readers will remember that when it was first announced that such a Commission would be appointed, it was given out that it would include no medical men. This determination altogether surprised and disappointed us. It was quite evident that a Commission without medical men on it would be in a fog from beginning to end of their work, unable to extract facts from the various witnesses, and equally unable to use the information elicited. We lost no time in showing this and in pointing out that a Commission so constituted would be obliged to seek some medical guidance, and would naturally seek guidance of the Medical Council, one of the bodies whose administration is complained of by those who are best able to judge. We have reason to believe that our arguments had weight in convincing many, members of the Government included, that medical men ought to be added to the Commission, for the double reason that they were deeply interested in medical legislation, and that they were most capable, by reason of their knowledge of the technical and complicated nature of the questions, of seeing and assisting others to see the points really at issue, and getting at the truth touching the working of the Medical Council and of the various examining bodies. When it was once determined to appoint medical men, it became a question how they were to be selected? Obviously it was not to be thought of that only such gentlemen as were known to be favourable to, or actual members of, the Medical Council were to be put on the Commission. Some names representing independence, and a knowledge of the educational questions involved, were required to satisfy the public and the profession. The names chosen will have this effect. It is to be regretted-seeing that the questions to be settled have reference chiefly to general medical practice in its broadest sense - that the Government have not seen fit to appoint a Commissioner familiar by experience with the present position of the general practitioner, and his relation to the public. But the profession will be well content to be represented by Sir WrLliam Jenner and by Professor HTXLEY. The too scanty representation of the profession on the Commission will naturally lead medical practitioners to look to Sir WILLIAM for the thorough investigation of questions which it is important to have settled. They will, we believe, not look in vain, and meantime we will accord our own thanks to him for agreeing-at what must be great personal sacrifice and inconvenience-to accept so important a duty. Sir WILLIAII was once a general practitioner, and though now moving in the highest spheres of consulting practice, is always showing his sympathy with those who are doing the hard work of common practice, in which work, too, he laid the deep foundations of that practical sagacity and knowledge of disease which now qualify him so well in guiding his brethren. He is well known also to believe that the existence of a Medical Council with no representative of the medical profession in it is one of the greatest anomalies. Professor HUXLEY will look at the questions which come before the Commission from a somewhat different standpoint from that of the medical practitioner, but he will not be out of sympathy with him ; and we shall be greatly disappointed if his influence is not used to simplify examinations, and to make the education that precedes them more thorough and more effective. Pro. fessor TuRNer and Mr. Srmon are members of the Medical Council; but the one represents such an enormous medical school, and such an efficient university, and the other is so able a medical statesman, and withal so anxious to make the Council worthy of the respect of the profession, that we cannot but commend the judgment of the Government in appointing them. The other members of the Commission will come to their work with various, though not medical, qualifications. An improvement in the Medical Boards and the Medical Council is an object of the widest interest to the public and to all classes. Politicians and statesmen may be apt to say this is solely a public question, and has nothing to do with the interest of the profession. We shall trust any body of educated men, and certainly this Royal Commission, to avoid such a narrow view as this-as if it were possible to dissociate the interest of the public and that of the profession on which it is most deeply dependent. The questions to be investigated and the problems to be solved by this Commission must form the subject of earnest consideration. We accept the appointment of the Royal Commission as an evidence of good faith on the part of the Government - not, as some would have us regard it, as a device for shelving or indefinitely postponing a great question, but as a means of establishing the profession in the esteem of the State, and securing to its members the possession of those rights which are the only set-off against the severe exactions and duties which are imposed on them by law and by the nature of their relation to the public. We publish in another column the terms of the Reference for this inquiry, as set forth in the Royal Commission, dated April 30th, 1881.

WHAT are euphemistically called "accidents" in lunatic asylums can scarcely be held to be numerous, when we consider the great total population of the insane ; its unequal dis. tribution; the relatively small number of attendants employed to maintain order ; and the large amount of personal liberty now commonly accorded to persons who are either in. capable of self-control, or-to their own knowledge-absolved from the duty of restraining their impulses by the fact of being "under certificate." Probably the aggregate return of assaults committed in an equal population of sane persons, of the same heterogeneous character as this multitude of so- 